\title{
WestVirginiaUniversity
}

THE RESEARCH REPOSITORY @ WVU

Graduate Theses, Dissertations, and Problem Reports

2011

\section{Surplus Value Extraction in Mental Labor in the Teaching \\ Profession}

Lindsey D. Felton

West Virginia University

Follow this and additional works at: https://researchrepository.wvu.edu/etd

\section{Recommended Citation}

Felton, Lindsey D., "Surplus Value Extraction in Mental Labor in the Teaching Profession" (2011). Graduate Theses, Dissertations, and Problem Reports. 883.

https://researchrepository.wvu.edu/etd/883

This Thesis is protected by copyright and/or related rights. It has been brought to you by the The Research Repository @ WVU with permission from the rights-holder(s). You are free to use this Thesis in any way that is permitted by the copyright and related rights legislation that applies to your use. For other uses you must obtain permission from the rights-holder(s) directly, unless additional rights are indicated by a Creative Commons license in the record and/ or on the work itself. This Thesis has been accepted for inclusion in WVU Graduate Theses, Dissertations, and Problem Reports collection by an authorized administrator of The Research Repository @ WVU. For more information, please contact researchrepository@mail.wvu.edu. 


\title{
Surplus Value Extraction in Mental Labor in the Teaching Profession
}

\author{
by
}

LINDSEY D. FELTON

Thesis submitted to the Eberly College of Arts and Sciences

at West Virginia University

in partial fulfillment of the requirements

for the degree of

Master of Arts

in

Geography

\author{
Approved by \\ Dr. Brent McCusker, Committee Chairperson \\ Dr. Kenneth Martis \\ Dr. Timothy Warner
}

Department of Geology and Geography

Morgantown, West Virginia

2011

Keywords: Value Extraction, Teaching Profession, Mental Labor, Labor Alienation 


\section{$\underline{\text { Abstract }}$ \\ Surplus Value Extraction in Mental Labor in the Teaching Profession By Lindsey D. Felton}

This research examines the labor of a public education school teacher and the value that is extracted from their labor. Teachers' working conditions and mental labor are assessed through qualitative research methods to help in explaining the various impacts and perceptions that teachers have within Monongalia and Preston Counties in West Virginia. Interviews and textual analysis research aided in uncovering issues of mental labor, labor exploitation, alienation of labor, and working conditions among teachers. Furthermore, how these issues coincide with the theory of surplus value extraction and the theory of labor alienation within Marxist literature. 


\section{$\underline{\text { Acknowledgements }}$}

I would first like to give a special thanks to all the research participants, who are not credited by name within this thesis, but provided this research with all the information that was needed to accomplish the goals of this research.

Secondly, I would like to thank the department of Geology and Geography and the West Virginia GIS Technical Center who have supported my academic career while at West Virginia University as a grad student.

Also, many thanks to my committee, who has been very encouraging and supportive during this thesis writing process. Thank you to Dr. Brent McCusker, Dr. Kenneth Martis and Dr. Timothy Warner for always pushing me to be a better student and academic.

Finally, I want to give special thanks to my family and friends who provided so much encouragement and tough love along the way to make sure that I got my thesis completed and that I graduated. All of you make everything better. 


\section{Table of Contents}

Abstract.............................................................................ii

Acknowledgements................................................................ii

Table of Contents.....................................................................iv

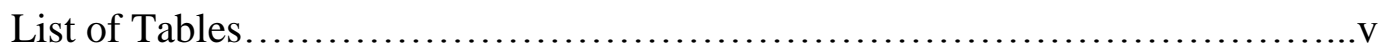

List of Abbreviations............................................................vi

Chapter 1: Introduction...............................................................1

Chapter 2: Theory....................................................................4

Chapter 3: No Child Left Behind.....................................................14

Chapter 4: Methods.................................................................22

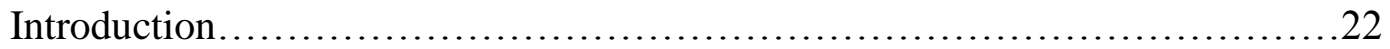

Qualitative Methods....................................................... 23

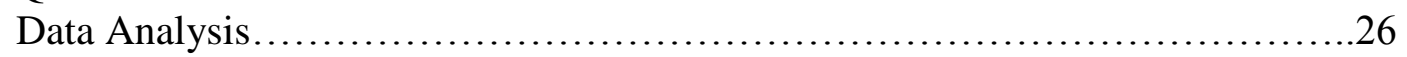

Chapter 5: Analysis...................................................................30

Critical Theory and Textual Analysis of Interviews........................... 30

Coding Framework...................................................... 31

Themes............................................................. 32

Chapter 6: Results.......................................................................35

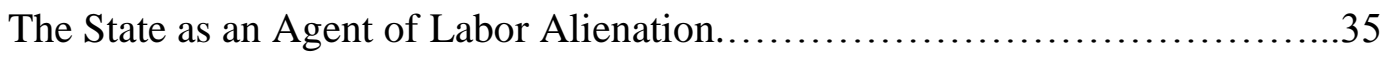

Attitudes............................................................. 37

Workload.............................................................. 38

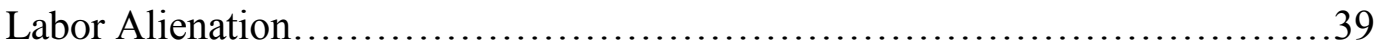

Workplace Conditions................................................4 41

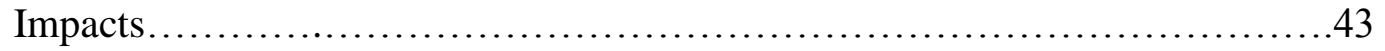

Consequences........................................................ 44

Chapter 7: Discussion.................................................................47

Labor Alienation.......................................................47

Labor Alienation of Teachers by the State on Behalf of Taxpayers..............50

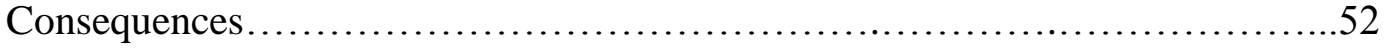

Chapter 8: Conclusion..............................................................55

Limitations to the Study.............................................56

References..............................................................................58

Appendix..................................................................................60

Appendix A: Interview Questions.....................................6 60

Appendix B: Cover Letter for Research Interviews........................662

Appendix C: Interview Consent Form ..................................63 


\section{List of Tables}

Table 1.1 - Coding Matrix for Content Analysis.................................. 32

Table 2.1 - Average Annual Salary of Teachers...............................41 


\section{Abbreviations}

AYP - Adequate Yearly Progress

CSOs - Content Standard Objectives

NCLB - No Child Left Behind 


\section{Chapter I- Introduction}

Similar to professions such as the law and medicine, teaching is founded upon an intensive course of advanced training. However, unlike these professions, teaching is one of the most underpaid and undervalued professions in advanced capitalist societies today (Ozga, 1981). According to Barry Farber (1991), the public education system in the United States is underfunded, providing few monetary resources for recruiting teachers.

Along with the lack of good pay, the regular school day hours are planned around instruction, which leaves teachers with very little time during the day for other essential tasks such as grading papers. This forces them to work in the evenings or on the weekends simply to perform job tasks required of them. Making very little money when compared to the amount of work they actually expend, this leaves many of them feeling undervalued and over-worked. Many teachers are unhappy with their working situation, whether it is because of new policies from the state, dealing with administrators, or just the ever-growing workload (Ozga, 1981).

In West Virginia the situation is no different and may be worse. There are several issues that West Virginia teachers are facing today. Due to legislation such as 'No Child Left Behind'(No Child Left Behind, 2011), the federal and state governments have, over the last several years, introduced new policies and testing standards that have added pressure to teachers regarding their performance in the work place and the ramifications if their school were not to meet the imposed standards.

Another issue is the professional status of teachers and how they are treated and used within the public education system. According to Michael Bayles (1981), a professional holds a certain amount of independence over his or her own labor. Unlike 
physical labor where the decisions are made by the employer on how the labor is going to used, professionals, such as teachers, provide mental labor. In addition, they "are autonomous insofar as they can make independent judgments about their work" (Bayles, 1981). This means they are allowed to exercise their professional judgment based upon the educational training they have received. Therefore, what sets teachers and other professional occupations apart from most labor organizations is that professionals and teachers utilize their mental capacity rather than their physical abilities to perform their required work.

In the case of teaching, teachers in a public education system have lost the autonomy over their 'mental labor' to their chief employer, the state. Through policies created by the state and its administrators, curricula are created that are meant to be strictly followed by the teacher. This process has deskilled the teacher and caused them to lose their ability to teach what they judge to be important based upon their professional judgment. They are reduced to a mere instrument, a menial worker for the state's wishes. As a result their 'mental labor' is being stretched far beyond what they are contracted to be paid while their labor is being alienated. Thus, in this thesis, I propose to examine the distinction between physical and mental labor in the context of the process of extracting surplus value from labor. Also, I will be addressing how teachers have responded against actions that alienate their labor.

There are several perspectives which one could examine the teaching profession. The goal of this study is to highlight and expose what is not being seen on the surface. Presently, there are numerous public teachers who are unhappy with not their career choice, but also how their profession is being controlled by their employer, the state. 
How do these teachers react and what are their perspectives on the controlling environments they are working in? An examination of relevant theory and literature will guide the research in this study and will aid in generating a better understanding of the processes and issues so far presented.

To understand these processes mentioned above, and in order to test the theory used in this thesis, I will examine the working conditions of West Virginia public education teachers within Monongalia and Preston Counties. I next turn to a brief statement of the problem, followed by a description of the study areas, Monongalia and Preston County; coupled with teachers' present status within these counties. I will then review the literature to further expand on the following concepts: the extraction of surplus value, mental labor and professionalism. Subsequently, I will present the research questions and goals of the proposal, along with the qualitative methods that will be used in this study. A thorough discussion on the data analysis and findings portions will be presented. In addition, a comprehensive discussion will be given on the interpretations of the data collected.

Although it is important to explain the consequences and impacts of state actions regarding teachers, it is necessary to first to understand the theory that will be utilized for the purposes of this study. The next chapter is an overview of this theory and discussion of its relevance to the topic of teaching as a profession. 


\section{Chapter II- Theory}

Labor theories have long occupied on important place amongst the discussions of economists. Among some of the more prominent labor theorists are Adam Smith, David Ricardo and Karl Marx. Although these men have contributed many concepts to the body of knowledge, for the purpose of this paper, their stances on the labor theory of value will be the main concern. Labor can be found in all forms of societies; whenever there has been a need for something humans have used their own resources to meet that need. Many minds throughout history have tried to explain the essence of labor and its functions and attributes in relation to value.

Smith held that in a primitive society, what determined exchange value of a good was the amount of labor put into it. However, in an advanced society, price is not proportional to the cost of labor because the value of the good now contains compensation for the possessor of the means of production. Smith states, "the whole produce of labour does not always belong to the labourer. He must in most cases share it with the owner of the stock which employs him" (Whitaker, 2001, 15). Ricardo argued in his labor theory that value of a good or product is relative to the amount of labor that was required to produce it, which in turn consists of the labor necessary to produce the raw materials and equipment used in the process. Ricardo explained this, "The value of a commodity, or the quantity of any other commodity for which it will exchange, depends on the relative quantity of labour which is necessary for its production, and not as the greater or less compensation which is paid for that labour" (Ricardo, 1817). For Ricardo, labor was just another means to measure value. Marx expanded upon Ricardo's labor 
theory of value and took it a step further. For the purpose of this paper, Marx's labor theory of value was chosen as a relevant theory to apply to the research questions.

Marx claimed that all human labor is value; in essence it creates value in an object or good. More specifically, this refers to labor power that is sold by wage workers. It was important for him to make a clear distinction between labor and labor power and eventually the surplus value that could be extracted from the labor power (Wolff, 1982). The distinction he made was that labor power becomes a commodity. It is what can be bought by an employer and sold by the worker. Once the labor power is sold by the worker, he then carries out their actual human labor. This produces a good for the employer which can then be sold to obtain a surplus value, because the wages paid to the worker are lower than what the value of the product which the worker produces.

Marx (1967) held that any object produced by humans obtains its value by the application of human labor. It is through this direct human labor that surplus value is created and exploitation occurs. To produce surplus value or a profit during any form of production process, there has to be a difference between what the employer pays the worker and the amount of value imbued in the product in the worker's act of creating it. Thus, a worker's day can be split into two parts. The first would be necessary labor time, which is the labor the worker expends to earn his or her wages paid by the employer. Second, the surplus labor time, which is the extra labor the worker has expended, that in essence the employer has not made compensation. This is the fundamental moment that exploitation occurs. Profit or surplus value forms from the action of unpaid labor (exploitation) in the production process. As Shapiro states,

When the laborer works a whole day for a price that only reflects the value he 
needs to survive, then he has unwittingly sold her or his labor time for less than its value. There is a gap between what price the employer has paid for labor time in the form of wages and the value created by that labor. The difference between the price paid for labor time and its value is the extra or surplus value that the worker has effectively 'given' to the employer for free (Shapiro, 2008).

In most cases in the literature, the theory of surplus value always refers to the physical labor that goes into the production process. As Harvey notes, "What the laborer sells to the capitalist is not labor (the substance of value) but labor power - the capacity to realize in commodity form a certain quantity of socially necessary labor time" (Harvey, 1982, 23). Profit, or surplus value, does not form from the exchange of products or commodities, but from the action of unpaid labor in the production process (Marx, 1967). This surplus, as Robert Wolff states, is found in the distinction between labor power (the ability to labor) and the 'activity of laboring' (labor). With labor comes production and with the end of any production cycle the capitalist will have goods "embodying more hours of labor than were embodied in the inputs used up to produce that output", which entails that extra or a "surplus value was extracted from the workers in the form of hours of laboring over and above what is socially necessary to reproduce their ability to labor or their labor power" (Wolff, 1982, 97). According to Marx, this surplus value extraction is labeled exploitation,

The worker becomes all the poorer the more wealth he produces, the more his production increases in power and range. The worker becomes an ever cheaper commodity the more commodities he creates. With the increasing value of the world of things proceeds in direct proportion to the devaluation of the world of men. Labor produces not only commodities; it produces itself and the worker as a commodity -- and does so in the proportion in which it produces commodities generally (Marx, 1967). 
Although exploitation is a constant aspect of capitalism and its modes of production, there is another concept that is essential to the issues being discussed, Marx's theory of alienation.

According to Marx, alienation of labor is a result of capitalism. "The theory of alienation is the intellectual construct in which Marx displays the devastating effect of capitalist production on human beings, on their physical and mental states and the social processes of which they are a part" (Ollman, 1976, 131). Marx's theory of alienation is established on his inspection that, within the capitalist mode of production, workers customarily lose willpower of their lives by being deprived of the right to consider themselves as the executive of their actions, to decide the character of their actions, to classify their relationship to other workers, and to use or own the value of what is produced by their labor. Ollman states,

"Man is spoken of as being separated from his work (he plays no part in deciding what to do or how to do it) - a break between the individual and his life activity. Man is said to be separated from his own products (he has no control over what he makes or what becomes of it afterwards) - a break between the individual and the material world. He is also said to be separated from his fellow men (competition and class hostility has rendered most forms of cooperation impossible) - a break between man and man. In each instance, a relation that distinguishes the human species has disappeared and its constituent elements have been recognized to appear as something else" (1976, 133-134).

Basically what Ollman is describing here is: alienation of a worker from himself as a producer, alienation of the worker from working (the act of producing itself) and alienation of the worker from other workers. Fundamentally, workers become autonomous human beings that are directed and diverted into goals and activities dictated by their employers, who own the means of production, in order to extract from workers the most surplus value possible. 
If a teacher is considered a professional worker, one who was autonomy over his or her labor, then the act of alienating a teacher from control over their own labor is reducing them to an unskilled worker. Aside from the lack of workers' control over the production procedures, in this case how things are taught in a classroom, alienation from the work produced refers more generally to the transformation of work, which is conducted to produce a use value in the form of a product. So the capitalist gains control of the worker, this includes creative workers, and the useful effects of his work by setting up a structure that alters the worker's efforts not only into a useful, concrete product but also an abstract concept, labor, which is rewarded in the form of wages at a rate as low as possible to sustain the greatest return for the capitalist.

A teacher, paid by the state, provides education to the children of the taxpayers of that state. From that statement, it is tempting to simply categorize teachers' labor as purely service based. Richard Walker's chapter in Reading Economic Geography (2004) offers another argument; that the label of service labor is thrown around carelessly and pinned to some occupations that he believes do not fall under that category. Walker splits labor into three levels in his conceptual framework, direct labor, secondary labor, and tertiary labor. Direct labor is labor that is expended directly on a product; it is the direct human labor that adds the value to a product. Secondary labor is just a step away from direct labor. Walker goes further by breaking secondary labor down into both auxiliary labor and preparatory labor. Auxiliary laborers' efforts cut down on the labor time expended by the direct laborers. Preparatory laborers' opens the way for more direct or primary labor. Both forms of secondary labor release the direct laborers from extra tasks. The third level Walker presents is tertiary labor, which is the realm of trade, 
management, banking, etc. This form of labor stands at a distance from the direct labor production process but still contributes to the overall integration and harmonization of the entire production process.

It is tertiary labor that could very easily be labeled service, but they are not because they "all stand at some distance from direct production, but contribute to the overall integration and coordination of a complex production system, the rate of capital accumulation, and the long term productivity of the economy" (Walker, 2004, 106). Walker argues that, "At the outset we may say that capitalist industrialism has not been transcended, but simply extended, deepened and perfected" (p. 105), thus presenting the point that ' "service activities rests on the productive power of the industrial system"(p. 105). Therefore, instead of simply labeling professions like teaching, as purely a service to the public, I argue that it is an integral a part of the production process. Although teachers are not producing a material object or any physical commodity, their work and expended labor is producing knowledge in students. This knowledge is later utilized directly in the process of primary, secondary, or tertiary production, thus reproducing the capitalist system that produces surplus value through exploitation.

This discussion leads us to an important question: what kind of labor does a professional teacher expend? Obviously teachers do not work in a physical factory nor do they physically turn out a product or good on a daily basis. Another distinction is that they are also not wage workers but salaried, like other professionals.

One of the issues that teachers face is the professional status of a teacher. According to Michael Bayles, a professional holds a certain amount of independence over his or her own labor. Unlike physical labor where the decisions are made by the 
employer on how the labor is going to used; professionals, like teachers, provide mental labor. In addition, they "are autonomous insofar as they can make independent judgments about their work" (Bayles, 1981), which means they are allowed to exercise their professional judgment based upon the educational training they have received. Therefore, what sets teachers and other professional occupations apart from labor organizations is that professionals, like teachers utilize their mental capacity rather than their physical abilities to perform their required work.

For the purpose of this paper, the status of a teacher as a 'professional' is taken into account. A professional does not fit exactly into the framework that Marx had laid out in his explanation of how a laborer functions within a capitalist society, but I maintain that a professional is still a laborer and thus the same theories can be applied to them. The literature thus far has conceptualized the position of a teacher being wedged in the spectrum between a professional and proletariat. According to Derber, teachers are labeled as an 'ideological proletariat' among professionals. An 'ideological proletariat' occurs when the worker has "lost control over the product, ... a loss of control over the goals and social purposes of one's work, its disposition in the market, its uses in the larger society, and the values or social policy of the organization which purchases one's labor" (Derber, 1982, 169). This concept can be applied to salaried professionals and in the case of teachers 'it (loss of control in the workplace) reduces the domain of freedom and creativity to problems of technique; it thus creates workers, no matter how skilled, who act as technicians or functionaries" (Derber, 172). In short, the profession of teaching transforms into "a salaried stratum increasingly integrated and absorbed within large scale capitalist production" (Derber, 1982, 172). 
It might be tempting to suggest that in occupations where there is no physical labor and therefore no materially based commodities or products, nothing is actually produced. However if we develop the concept of mental labor already mentioned, then the idea of the production of knowledge can be developed. In many cases this is one of the most difficult moments to pin point, the production of knowledge, but still contributes to capitalistic production, but at a considerable distance. In essence, the production of knowledge contributes to direct labor. In turn, the labor from producing knowledge, such as education, which "prepares the worker for learning tasks and solving problems" (Walker, 2004, 107), are therefore considered "preconditions for the ordinary labor of all kinds, and add in obvious ways to the growth of labor productivity over time" (Walker, 2004, 107).

At this point a distinction between productive and unproductive labor should be discussed. Productive labor adds value to the system, in our case the capitalist system. However, unproductive labor adds no value and does not additionally add to the end of the system. Smith would follow this line of logic:

There is one sort of labour which adds to the value of the subject upon which it is bestowed; there is another which has no such effect. The former, as it produces a value, may be called productive; the latter, unproductive labour. Thus the labour of a manufacturer adds, generally, to the value of the materials which he works upon, that of his own maintenance, and of his master's profit. The labour of a menial servant, on the contrary, adds to the value of nothing. Though the manufacturer has his wages advanced to him by his master, he, in reality, costs him no expense, the value of those wages being generally restored, together with a profit, in the improved value of the subject upon which his labour is bestowed. But the maintenance of a menial servant never is restored. A man grows rich by employing a multitude of manufacturers; he grows poor by maintaining a multitude of menial servants. The labour of the latter, however, has its value, and deserves its reward as well (Smith, 2003: 429-430). 
From this excerpt it would be easy to categorize a professional teacher as a menial servant who is employed by the state and returns no profit to their employer after a day's worth of laboring in the classroom. However this is not the case. Sweezy believes Marx would argue that,

On the one hand all labor is, speaking physiologically, an expenditure of human labor power, and in its character of identical abstract human labor, it creates and forms the values of commodities. On the other hand, all labor is the expenditure of human labor power in a special form and with a definite aim, and in this, its character of concrete useful labor, it produces use values (Sweezy, 1970, 29-30).

I would argue that, all human labor and all labor power expended is the substance of all value. This includes the laboring of a professional teacher. Their mental labor does not produce a materially existing good or product, but it does create value into their students, whom are the potential workers in the capitalist system. The skills and knowledge they are learning in the classroom setting is adding to the value of the system as a whole, but it hasn't materially manifested itself yet into a product. This specifically applies to the profession of a teacher, where I argue that they are producing knowledge. Producing knowledge has few tangible material outcomes; as a result, it is difficult to specifically isolate or measure. Examination of the creation and extraction of surplus value in the process of mental laboring as it pertains to a teacher provides indirect labor in the classroom can be accomplished through the critical application of Marx's theory of surplus value extraction and theory of alienation.

Marxist writings and theories do not cover mental labor as extensively as some other concepts. Although few works are concerned with the exploitation or the alienation of mental labor, this project considers this topic to be extremely important and essential 
to explaining the distinction between it and physical labor. This has introduced particular concerns for this paper. A reconfiguration of the definition of surplus value and the application of the theory of alienation of labor was employed to be able to apply it to the realm of mental labor. Several issues have arisen with this. For instance, who is ultimately the capitalist in this process of production? Who benefits from the surplus value or profit from the mental labor? Does the surplus value or profit stay in one place or is there a circuit it moves through? Thus, an examination of the distinction between physical (direct) and mental (indirect) labor, in the context the process of extraction the surplus value from teachers' labor will be covered in the data analysis section of this paper. Also addressed will be how teachers have responded to such exploitative actions, such as by joining associations. Furthermore, there are multiple movements of the value contained within the produced knowledge. Those do not merely force a movement from one point to another and stop. This will also be discussed later in the discussion chapter. 


\section{Chapter III- No Child Left Behind}

The Act of No Child Left Behind Public Law 107-110 was passed by Congress in 2001 and signed by President George W. Bush in 2002. This was the federal government's attempt to reform and fix the "problems" associated with the elementary and secondary schools in the public education system in the United States. Specifically, it found that "the academic achievement gap between rich and poor, Anglo and minority is not only wide, but in some cases is growing wider still” (NCLB, 1). Thus, the need to lessen this gap and no longer "leave behind students" became a priority. This law represented a set of initiatives that would "radically transform the federal role in policing and controlling core aspects of education" (Apple, 2007, 109). Congress claimed this effort was centered on the student, according to the federal government, which can be illustrated by the ideological quote the prefaces the bill, "The federal role in education is not to serve the system. It is to serve the children" (NCLB, 1).

Due to legislation like No Child Left Behind, federal and state governments have, over the last several years, integrated new policies and testing standards. NCLB was presented as a framework that would re-work the education system by promoting and encouraging more accountability to schools and the administrations that run them.

From its inception, there have been many educators/critics of the bill. The chief criticisms were: it was believed that the increase in accountability assessments imposed on schools would cause more harm than good. The consequences that NCLB enforces against schools who don't meet test score standards will ultimately hurt poor communities and schools the most. Along with accompanying tutorial programs derived from NCLB public money will predominately go to private companies." NCLB is part of 
a larger political and ideological effort to privatize social programs, reduce the public sector, and ultimately replace local control of institutions like schools. Marketplace reforms that substitute commercial relations between customers for democratic relations between citizens" (Karp, 2003, 4).

It is this last criticism that will be the main focus for the purpose of this thesis. Rentschler states, "Some critics argue that the NCLB is merely a backdoor route to private school vouchers and the privatization of public education by demonstrating the failure of public schools. These critics claim that NCLB's lofty goals are intentionally impossible to meet, and the end result will be massive numbers of public schools failing across the country" (Rentschler, 642). The criticism that Rentschler is referring to is from Stan Karp, who has been a teacher for twenty seven years in New Jersey and is a self proclaimed 'school reform addict'. Karp is very outspoken against the framework of the NCLB bill, among other educators. Karp offers this at a talk in 2003, sponsored by Portland Area Rethinking Schools. "There are so many things wrong with this law, so many things that are educationally inappropriate and hostile to the welfare of public education" (Karp, 2003, 1) and he later states "the Bush Administration is trying to use NCLB to promote an aggressive agenda of privatization, including attempts to revive a voucher movement that has been defeated in every state referendum where people had a chance to vote" (Karp, 2003, 4).

To bring about more accountability for teachers, a system of assessments and testing was and implemented that would provide a way to measure students' progress in the classroom. This, in turn, would be the indicators for the level of a teacher's performance. For instance, the West Virginia statewide test known as the West Test revolves around testing and holding schools and teachers accountable for their 
performances. Teachers are thus being bound tighter by more rules and guidelines which prevent them from teaching as they have been trained. However, the consequences of not meeting these implemented standards have provided the footing for "a larger agenda of privatization and marketization" (Apple, 2007, 110). Indeed, the bill itself provides such an argument,

"Schools that fail to make adequate yearly progress for disadvantaged students will first receive assistance, and then come under corrective action if they still fail to make progress. If schools fail to make adequate yearly progress for three consecutive years, disadvantaged students may use Title I funds to transfer to a higher-performing public or private school, or receive supplemental educational services from a provider of choice" (NCLB, 3).

For instance, "funding will be provided to assist charter schools with start-up costs, facilities, and other needs associated with creating high-quality schools" (NCLB, 5) and "consequences for Failure, the Secretary of Education will be authorized to reduce federal funds available to a state for administrative expenses if a state fails to meet their performance objectives and demonstrate results in academic achievement" (NCLB, 5).

The NCLB bill also states,

"Systems are often resistant to change - no matter how good the intentions of those who lead them. Competition can be the stimulus a bureaucracy needs in order to change. For that reason, the Administration seeks to increase parental options and influence. Parents, armed with data, are the best forces of accountability in education. And parents, armed with options and choice, can assure that their children get the best, most effective education possible" (NCLB, 18).

It is in this statement that the true process of privatization can be seen hidden behind the discourse of having the children's interest in mind. Competition as defined in Merriam-Webster dictionary is, "the effort of two or more parties acting independently to secure the business of a third party by offering the most favorable terms". By schools not meeting the decided upon government standards 
will potentially result in funds moving from the public school systems and into the hands of for-profit organizations.

Michael Apple (2007) offers an interesting point in his article, "Ideological Success, Educational Failure?: On the Politics of No Child Left Behind". He puts forward an argument that suggests that dominant groups often listen to sub groups and their demands for change or reform. They then try to capture their discourse and rework it so that it means something else. Apple believes that NCLB is one of the best examples of this and states,

"Reforms are then instituted that do not threaten dominate groups' agendas. Rather they respond not to the original meanings inherent in key concepts within the discourse but to policies that create conditions that dominate groups are able to control or that extend the influence of such groups in the sector of society out of which the concerns come" (Apple, 2007, 110),

Among his other critiques of the bill itself and its 'hidden effects', he holds that the bill leads to an underlying agenda of privatization in education. It's hard not to notice that "the underlying logic of NCLB sutures together the requirements of strong accountability measures with an even further opening toward funding for private education and marketization” (Apple, 2007, 111).

There are others who share similar sentiments as these. David Hursh, who has long been involved in education and opposed to NCLB policies, has comparable opinions on the subject. "NCLB is part of a larger change in social policies in particular, the rise of neoliberal economic and social policies that have become dominant over the past few decades" (Hursh, 2007, 495). Hursh continues suggesting that neoliberalism "emphasizes 'deregulation of the economy, trade liberalization, the dismantling of the 
public sector [including education, health and social welfare], and the predominance of

the financial sector of the economy over production and commerce"” (Hursh, 2007, 495).

David Harvey speaks of neoliberalism and its push for markets to gain access to all

levels, "if markets do not exist (in areas such as land, water, education, healthcare, social

security or environmental pollution) then they must be created, by state action if

necessary" (Harvey, 2005, 2). Some neoliberals argue,

increased efficiency can only be attained if individuals are able to make choices within a market system in which schools compete rather than the current system in which individuals are captive to educational decisions made by educators and government officials. Furthermore, if individuals are to make decisions, they must have access to quantitative information, such as standardized test scores, that presumably indicate the quality of the education provided. Neoliberals believe competition leads to better schools, and hence better education for students, closing the achievement gap between students of color and White students (Hursh, 2007, 498).

As previously mentioned, one way NCLB pushes for privatization of education is through the implementation of standardized tests such as the West Test in West Virginia. As Hursh says, "many neoliberals argue that standardized testing will increase educational opportunity and ensure greater assessment objectivity than teachers provide" (Hursh, 2007, 494). NCLB clearly states, "Annual reading and math assessments will provide parents with the information they need to know how well their child is doing in school, and how well the school is educating their child. Further, annual data is a vital diagnostic tool for schools to achieve continuous improvement" (NCLB, 3), which means data collected, becomes the main means at determining whether a school is meeting Adequate Yearly Progress (AYP) standards, is a standard defined by the No Child Left Behind Act that permits the U.S. Department of Education to decide how every public school and school district in the country is performing academically according to results 
on pre-determined standardized tests. Essentially, it is the test scores of individual students that provide the numbers and data that determines the progress and performance of a school. This data is then collected statewide and used to compare which schools are performing well or falling short of the state's standards.

Data collection has been a crucial aspect and the means for NCLB and its underlying push for the materialization of the market in the public school system. This is evident in the concept choice that the bill offers, "indeed, the movement toward marketization and choice requires the production of standardized data based on standardized processes and products so that comparisons can be made and so that consumers have relevant information to make choices on a market" (Apple, 2007, 111). As NCLB states, "and parents, armed with options and choice, can assure that their children get the best, most effective education possible" (NCLB, 18), which means choice, is now an option for parents when it comes to where they want their kids to attend school. It is the mechanism and process of standardized testing and data collection that NCLB has employed that has set the stage for the market to infiltrate into the public education system. Students' parents, essentially, have become consumers in the education market as they have now been provided the option to 'shop' around for education they want for their children. Once numbers can be applied to the knowledge and learning progress in students based on their standardized test scores, a school's education can then be transformed into a commodity. It has become a product that now parents have a choice over. With education being perceived as a product, it can then "serve different ends",

Thus, rather than schooling being aimed at creating critically democratic citizenship as its ultimate goal, the entire process can slowly become aimed instead at the generation of profit for shareholders or a site whose hidden purpose is to document the efficiency of newly empowered 
managerial forms within the now supposedly more business-like state (Apple, 2007, 114).

It is evident that there are underlying pushes for privatization and the adoption of the market in education included in the NCLB bill. The problem is not trying to identify them, but to now recognize the problems and issues they are causing in the current system. There has been extensive research in states New York and Texas on the failings of the standardized tests and how administrations have manipulated figures and data to meet standards imposed on them. It appears that "the aim of NCLB and other high stakes testing reforms may be less about improving student learning and closing the achievement gap than it is about undermining public education to introduce a market based system" (Hursh, 2007, 504). Other issues surrounding NCLB are the pressures that individual teachers are feeling as a result of the higher standards. Teachers are beginning to teach to the tests; "because of the pressure to raise test scores, particularly in the urban school districts, teachers are compelled to teach the skills and knowledge that will be tested, neglecting more complex aspects of the subject and indeed some subjects all together" (Hursh, 2007, 506).

NCLB, according to its critics, has shown to be an ineffective education reform and it has also primed the move forward for a more private and for profit educational system. The state has positioned itself to take the lead in educational decisions when the public schools fail to meet the imposed standards on them. "Under NCLB, the important educational decisions are made by the federal and state governments. Individuals are cast as consumers who can choose among the choices provided by an educational marketplace” (Hursh, 2007, 514). Fundamentally, NCLB has been unsuccessful at 
providing objective assessments that would reveal whether a school is improving. It has also readied for the dissemination of a neoliberal 'educational marketplace'. 


\section{Chapter IV-Methods}

\section{Introduction}

West Virginia is one of the poorest states in the country, so it is of no surprise that the teachers of West Virginia are some of the most underpaid in the nation. According to the American Federation of Teachers' (AFT, 2007) Survey and Analysis of Teacher Salary Trends 2007, West Virginia ranked 45th in the nation for its average teacher salary in 2006-07. The average salary of a teacher in West Virginia was $\$ 40,534$ according to this survey. With such a low salary, West Virginia teachers are an appropriate group to pursue an examination and analysis of labor alienation. To understand the processes mentioned above and in order to appreciate the theory behind these statements so far mentioned, I will examine many aspects of basic working conditions of a teacher, such as: salaries, student-teacher ratios (including classroom size), workload (time spent in and out of the classroom on paperwork), autonomy of work related decisions in the classroom and the implementation of state policies and initiatives within schools and classrooms. This examination will focus on West Virginia public education teachers within Monongalia and Preston County.

Although these two counties share a common border, they differ in other ways, such as population size and per capita income. Monongalia County has a population of 88,221 people, is majority white, non-Hispanic population. The county has seen a $7.8 \%$ population growth between the years of 2000-2008. In comparison, Preston County has a population of 30,285 people, with demographics very similar to Monongalia County, although will only a 3.2\% population growth between $2000-2008$. 
Even though there are some noticeable differences between the two counties, teachers in both counties, I believe, share a common alienation of labor by the state. The examination of teachers employed by these counties will be through the use of qualitative methods, primarily interviews and focus groups. Interviews were chosen as the primary research method for this study because of their ability to provide perspectives that only the informants in this particular study can supply. They will assist in the investigation of behaviors, motivations and responses to issues that have been addressed in this problem (Dunn, 2005). This form of methodology was chosen because it was believed that it would be the most appropriate route to answer the research questions:

1) Through what processes is surplus value extracted from mental laborers?

1a) How does mental surplus extraction compare and contrast to physical surplus labor extraction?

1b) Does a distinction need to be drawn?

2) How have teachers reacted to surplus extraction within the teaching profession?

2a) How do teachers perceive unions and their effects on labor relations?

\section{Qualitative Methods}

Qualitative methodology was chosen as the primary research method for this project. The reason for this was that there are two fundamental questions that qualitative researchers are concerned with social structures and individual experiences. Question one is "What is the shape of societal structures and by what processes are they constructed, maintained, legitimized and resisted?" (Winchester, 2005, 6). The second question is: "What are individuals' experiences of places and events?" (Winchester, 2005, 7). These particular questions helped guide research for this project because the aim of this research is to examine the social and labor structure of teachers. Also to be noted is their labor 
relations with their employer to acquire their perceptions and views of these social structures, because "structures constrain individuals and enable certain behaviors, but in the some circumstances individuals also have the capacity to break rather than reproduce the mould" (Winchester, 2005, 5). I chose this methodology was also because although "qualitative geographers balance a fine line between the examination of structures and processes on the one hand and of individuals and their experiences on the other" (Winchester, 2005, 5). It is, therefore, the examination of both of these aspects that provide the most vital and essential information for this type of project.

With the research questions specified, it was easy to decide that qualitative methods were going to be the best option for this project. The reason for this is qualitative methods allow to probe deeply into respondents perspectives in a more efficacious manner than quantitative methods.

Question One:

1) Through what processes is surplus value extracted from mental laborers?

la) How does mental surplus extraction compare and contrast to physical surplus labor extraction?

1b) Does a distinction need to be drawn?

To answer this first question specifically, a critical application of Marx's theory of surplus value is used. This will be done through the extensive use of literature on the theory of surplus value. To accomplish this task, themes from the literature, including exploitation, human labor, mental labor, and value extraction will be used when analyzing the interview data. In addition to the application of the theory of surplus value, responses collected from the interviews provided a means to help answer this initial question. 
For the remaining questions:

2) How have teachers reacted to surplus extraction within the teaching profession?

2a) How do teachers perceive unions and their effects on labor relations?

Interviews were the main method used to address the remaining research questions.

They provided the necessary information on how teachers have responded and reacted to the processes that have been stated above. Specifically, the interviews offered insights on how teachers of Monongalia and Preston County view each other and their education systems. Most importantly, interviews provided this research with the essential data on how teachers have perceived the actions that have been carried out around them and towards them. In particular, key informant interviews supplied important information that assisted in answering questions raised during this study. Another reason for interviews as the primary method was because they are a valuable resource that helped answer not only the research questions that were created for this project, but also the two much broader questions that concerned themselves with identifying social structures and how they operate. Interviews also aided in discovering how people or individuals act within, and experience these structures. The interview process presented information that only the participants involved could supply because they are the only ones who have experienced what is being studied and "people's own words do tell us a great deal about their experiences and attitudes. But they may also reveal key underlying social structures" (Winchester, 2005, 9). The goal of this research was to highlight and tease out any social structures that were present, whether at surface or below.

The interviews were conducted in a semi-structured style so that the questions were presented in a predetermined order but still ensured flexibility in the way the issues 
were addressed by the informant. Questions were presented in a funneling structure. This format began with more general questions that focused on broader issues and eventually moved towards more personal issues or subject matter that pertained to the informant (Dunn, 2005). I set a goal of obtaining no less than 12 interview participants. Interview participants were chosen by selecting key informants, relying on a snowball sampling method. Each participant had to meet the requirements of being a current teacher in either Monongalia or Preston County. The criteria also called for each candidate to be a regular (K-12 grade) education teacher.

Questions used in these interviews were formulated based on the already created research questions. In addition were the working condition indicators: salaries, studentteacher ratios (classroom size), workload (time spent in and out of the classroom on paperwork), autonomy of work related decisions in the classroom and the implementation of state policies and initiatives within schools and classrooms. These questions expectantly provided this project with the essential information, which only teachers can provide on these issues presented, to offer valid findings.

\section{Data Analysis}

To analyze all the data collected, different approaches were used. To begin with, all interviews were transcribed. A manifest content analysis was conducted, which evaluated the visible or surface content of the interview. A latent content analysis, which involved investigating the interview's themes, was also incorporated. A manifest analysis looks at the obvious. An example would be how frequently a word is used and in what context is it used. Also they are the most apparent within the interview. These codes that 
follow this form of analysis will hint to the importance of something because of how frequently the word is used. A latent content analysis focuses on themes that are revealed during the interview process, which allows the researcher to identify underlying issues (Peace, 2005).

This second form of analysis was the most useful in answering the research questions because this form of analysis aided in revealing which themes or issues were being addressed. Specifically, contradictions between processes were revealed through the information gathered from a key informant when compared to data gathered through actual research done by the researcher.

During the process of analyzing all the data, a coding framework, described see below, was utilized and applied to the transcripts. Coding was necessary because "coding refers to the preliminary stages in qualitative analysis where the data are combed through by the researcher, marking up the transcripts with a series of 'codes' that label particular words and phrases for subsequent analysis" (Jackson, 2001, 201). The research questions and the previously stated working condition indicators guided the coding framework for this project. This coding process created a more systematic interpretation of the data throughout the whole process, so everything was analyzed in the same way. For the coding process, Nvivo was used to help with the organization of the interviews. This aided in the data analysis portion of this project.

Computer software for qualitative data analysis, such as Nvivo, have both advantages and disadvantages and concerns. One of the biggest benefits of using computer software is the speed at which tasks can be performed. For instance, the process of coding itself is as well as the retrieval of those coded segments in later phases of the 
analysis is very efficient. Nvivo potentially can save a researcher time, but only if the researcher is familiar with the software. There has also been some criticism that the use of computer software in data analysis alienates the researcher from the data. In other words, the machine takes over and can make the research appear scientific (Peace and Hoven, 2005). It is also important to note that most of the analysis relied on typed transcripts, which supresses emphasis or hesitation on certain words or phrases. As a result, it was important as researcher to go back and listen to the recorded interviews many times.

All information gathered during the interview process was kept completely confidential and a separate key was kept that linked a participant to their responses. In addition to this, all interview recordings were kept secure and retained only for the use of the primary researcher. All participants in both interviews were informed of the project before the interview and the goals of the research were explained and shared with them. They were also informed that the entire interview was voluntary, and if at any time they felt uncomfortable answering a question, they were under no obligation to respond. Each participant was presented with a cover letter explaining the scope of the project and informing them of the measures that would be taken to ensure their confidentially.

Being raised by two public education teachers and having several other family members and friends who are teachers has given me, what I believe to be, an insider relationship with teachers. I felt that some sort of relationship had already been established with teachers. This gave me an advantage while interviewing teachers because they may have felt more open to talk with someone who already had an understanding of their job. On the other hand, I am not a professional teacher, thus I was 
still an outsider to the profession. So there may have been some resistance to answering questions openly. So although my upbringing around teachers may have made the participants' responses more forthright and accessible to share their opinions and concerns with someone who is not part of the teaching community, there could also have been some resistance. It therefore was important to keep in mind these insider/outsider issues and to find ways to relate or make the participants feel at ease while participating (Aitken, 2001).

It was also important to keep in mind my positionality during the whole course of the research process. It could have become tempting for me to become too biased about the information I chose to present or omit during the writing process of this project. Therefore, it is of the upmost importance to acknowledge my position within this work and make the reader aware of my background when concerning the profession of a teacher.

To accomplish the interviews and to stay aware of these issues, I was required to obtain Collaborative Institutional Training Initiative (CITI) training on human subjects. This process teaches and educates a researcher on the proper ethics and actions when using human subjects in research. In addition to this training, I obtained Institutional Review Board (IRB) approval, which is a review board within the university that looks after the interests of human subjects in research. 


\section{Chapter V-Analysis}

\section{Critical theory and Textual Analysis of Interviews}

The goal of this research was to examine the social and labor structure of teaching, teachers' labor relations with their employer. Also, I needed to acquire the treachers' perceptions and views of these social structures, because "structures constrain individuals and enable certain behaviors, but in the some circumstances individuals also have the capacity to break rather than reproduce the mould" (Winchester, 2005, 5). This was accomplished by a thorough examination of relevant literature on these particular issues. Also the process involved several key informant interviews. I proceeded to contextually analyze the transcripts of the interviews and investigated how the informants' responses aligned with the theory being applied to this study.

Before analysis, I assigned each informant a number so as to maintain respondent anonymity. This assured that no information could be in any way tied to them. I began analyzing the data by first separating all of the interviews into two groups. These groups were based specifically on location, whether the individual teacher taught in Monongalia County or Preston County. The reason for this division was to maintain that a comparison could be made between the responses given by the two differing groups. I believed this would reach differences in themes. In addition, I would be able to ascertain whether or not location of work, wealth in the county or lack thereof, or county school management of the county schools had an influence on the responses given. 


\section{Coding Framework}

When first analyzing the data, a manifest content analysis was utilized. It was this initial analysis that helped to formulate and finalize the code key. This form of analysis involved investigating and looking into the interview's most obvious and surface level themes. From the beginning of this study, certain interview questions were formulated in expectation of certain topics being discussed. So, although some potential codes where known ahead of time, there were others that the preliminary manifest content analysis revealed. The codes that were then created reflected the initial themes that were presenting themselves throughout the ongoing interview process.

My content codes are fairly obvious and straight forward. I formulated five manifest content codes: government, labor in the classroom, salary or pay, work place conditions, and workload. Although these codes refer to something specific, during the interview process there were several issues that came up under these topics. For example, when several of the key informants referred to the 'government', this included other topics such as policies, initiatives that impact schools and the classroom. It is also important to note that, in the interview process when talking about the government, all levels discussed but the primary focus was on the county and state levels.

A much larger list of latent content codes was created that focused on issues and themes that arose during the literature reviewed for this study and through the interviews as well. The finalized codes: labor alienation, classroom autonomy/creativity, attitudes (teacher's perceptions), consequences, teacher roles, accountability, outsiders' perceptions, support, standardized testing, impacts, and state involvement. It was these latent codes that were most helpful in answering and revealing insights into the issues 
that are presented in the literature review section of this study. Standardized testing highlights the government's involvement in the public education system. Most of these codes are straightforward in their meaning and was apparent in the transcribed text; however, others were created based on phrases and certain remarks given by the respondents. Below is a table that shows the code and theme words used in the analysis.

\begin{tabular}{|l|c|l|c|}
\hline \multicolumn{3}{|c|}{ Table 1.1 - Coding Matrix for Content Analysis } \\
\hline Manifest Codes & $\begin{array}{l}\text { Word } \\
\text { Count }\end{array}$ & Latent Codes & $\begin{array}{l}\text { Word } \\
\text { Count }\end{array}$ \\
\hline government & 15 & labor & 14 \\
$\quad$ policy & 12 & alienation & 22 \\
$\quad$ initiatives & 17 & autonomy/creativity & 26 \\
labor in the & 71 & attitude & 10 \\
classroom & 192 & consequences & 19 \\
$\quad$ work & 100 & accountability & 8 \\
salary or pay & 7 & outsiders & 5 \\
work place & 13 & support & 82 \\
conditions & & testing & 147 \\
workload & & state & 155 \\
\hline
\end{tabular}

*Table above shows the coding matrix used when counting the frequency at which words were used and/or discussed during the interview process.

\section{Themes}

The specific themes that I chose were the issues most prevalent in the responses of the teachers. For the scope of this particular study, other themes that did not play a vital role in the specific research questions being asked were omitted from the analysis process. An example of this was the issue of the students themselves. Although I find the welfare and the education interests of all students important, for the purpose of this study, it was omitted. The main concern were the roles of teachers, how their labor is expended, and in what forms. 
To assist in keeping the data organized and in order to ensure the most systematic approach to analysis, the codes where grouped together based upon relation to each other. This procedure helped in separating specific themes within the data and made it easier when interpreting the responses given during the interviews. For example, I grouped all codes that involved anything dealing with the government, such as standardized testing, policies, initiatives implemented in the classrooms, and the accountability of teachers. Another group of codes consisted of everything that dealt with the workplace, including: work place conditions, teacher roles, support, and autonomy over decisions made in the classroom. A third group of codes focused on labor, labor alienation, workload, and salaries in relation to the amount of work. The final and fourth group concentrated on attitudes, teacher perceptions, non-teacher perceptions of the profession, consequences they feel they undergo, and their interpretations of the state of the West Virginia public educational system. I believe these themes are very important because they expose teachers' perceptions and understanding of the system that they work in. They also show how those attitudes easily switch between negative and positive depending on the topic being discussed. This theme will be further elaborated in the discussion chapter of this thesis.

The majority of interviews lasted fifty minutes to an hour. Every respondent was very open and willing to share their thoughts and insider information on the questions asked of them. With the respondents knowing ahead of time that their responses were going to be kept confidential, I believe the teachers felt more at ease and open to responding freely with their opinions on these issues. Without the fear of repercussions regarding what might be said about their individual administrations or county educational 
systems, the teachers' answers were more forthcoming and helpful. It will be these relationships and processes that will be further discussed in more detail and thoroughly in the discussion chapter. 


\section{Chapter VI- Results}

The State as an Agent of Labor Alienation

Initial research and reading had already informed me to some of the ways the government; in this case, county (Board of Education), state (West Virginia Department of Education) and federal (U.S. Department of Education) governments are all involved in influencing labor conditions. Since the educational system in the United States is public, and all public teachers are employed by some form of government, all teachers experience the state's involvement to varying degrees.

The interviews indicate that the teacher's perceptions and feelings regarding the extent of government involvement were very similar. The majority of the teachers that I spoke to gave indications of being unsatisfied with the level of involvement by the state, although this varied from too much to too little. One example of government involvement that all teachers interviewed expressed dissatisfaction with was the policy known as No Child Left Behind and the mandates it created. More specifically, displeasure was voiced with regards to adhering to the state's content standard objectives or Content Standard Objectives (CSOs) that are enforced and required for all teachers to implement in their classrooms. It's these CSOs that the main standardized test for West Virginia is based on the so-called West Test. The teachers were asked about these CSOs and all explained them as objectives that the state requires to be accomplished. These are the objectives that, in theory, will prepare children for the next grade level. However, many feel the CSOs are geared more towards scoring higher test scores on the West Test. CSOs are viewed as something that there is no comprise. They are mandated. "So you pretty much stick to those CSOs, you really have to" and "...but that is one of the things they 
[administrators] check for, like when they check your lesson plans, they look to see if you are teaching the CSOs" are statements that essentially sum up the responses regarding CSOs.

Between the two counties, government involvement did vary slightly. According to Informant 1, who taught in Monongalia County, there are some counties, such as Preston, where the state observes what they feel are problems and consequently have taken over. One went on to say, "You know the state department of education takes over the whole county and you know they start making the decisions in regard to replacements and what is done there". In another interview Informant 3, who teaches in Preston County, was asked about this and said the reason was because of "certain indiscretions and low test scores" in the county. She elaborated by offering an example of what had been changed by the state, “They appointed the superintendent; it wasn't county appointed". In discussing this example they indicated they were feeling the effects of this change. They went on to share that they had been hired for another job the next year but were unsure of the security of it because everything had to be forwarded to the state for approval. As they explained, "So it is like we are being run from Charleston, which kind of makes it hard to do your job in Preston County". It is of no surprise that it is hard for teachers to do their job when they are being administered by people who are not even present and running things from afar. It is hard for a teacher to adequately perform their duties when they need things or need guidance and the people they go to our absent or they have to go through multiple channels. When there is no control at the local level and you are at the whim of the state, a teacher loses autonomy and control over their working conditions. 


\section{Attitudes}

The primary focus of interviewing these teachers was to gain an insider's perspective. The interviews also provided an opportunity to experience their environment and actions carried out around them. I also wanted to discover how they felt, based on their own work experience. Also I sought, in general, their attitudes towards the teaching profession itself, their interactions with their administrations and the government.

Splitting the interviews into two groups based on location of job proved to be very helpful when comparing attitudes. In general, respondents from Preston County had more negative and attitudes that indicated feelings of disenfranchisement towards the public education system as a whole than their counterparts in neighboring Monongalia County. Many spoke in terms of an 'us' versus 'them' mentality when the topic of the state or county board office was brought up in discussion. Several of the respondents from Preston said more than a few times how they saw the county office as being in it all for themselves, money being the bottom line, not having the teachers interest at heart, and being there to promote themselves politically (Informant 3, Informant 2, Informant 7 , Informant 9).

In comparison teachers in Monongalia County appeared to be aware of what they felt to be the shortcomings of the board office, but spoke of it in a more positive light. However, within both counties, it was apparent that most of the teachers had very little interaction with the county board offices and even less at the state level. Some even felt as if they were very removed from the system, which they felt was only there to carry out 
the bidding of the state. Do exactly as the state says and not to cross them (Informant 3, Informant 1, Informant 5, Informant 7, Informant 9).

Most teachers experienced attitudes of concern, apprehension, blame and feelings of being taken advantage of. Although there were some positive statements in the midst of the more negative responses, they were very few and far between. Teachers explained their feeling as being a result of empty promises, lack of support, and disregard for teacher input. These issues came up when I asked questions such as: How are your working relations with your administration and if you were in charge of an administration how would you run things?

\section{Workload}

Workload reflected the quantity of work a teacher, on average, is required to maintain and accomplish within any given week. This consists of paper work such as, grading papers and administrative forms for students, lesson planning, preparing materials for lessons and any extra content research that they feel is needed for a lesson. It became apparent during the interviews that many of these tasks and expectations of the teacher are done outside of the classroom and the regular working contracted hours.

Among all the teachers that I interviewed, I can safely say that among all the topics and issues we talked about the majority of the focus was about their workloads. Each teacher was asked if he or she felt they had overly-demanding workloads and every one of them answered 'yes'. Their workloads varied in degree, but largely all of them consisted of work that had to be completed outside of the regular working day because of various things like meetings, which took up planning periods, the increased amount of 
instruction time they had to perform, and the state-encouraged $21^{\text {st }}$ Century learning programs that centered around technology and preparing for the West Test (Informant 2, Informant 11, Informant 4, Informant 5, Informant 8).

One issue in particular that stood out was the fact that on top of all the instruction time and CSOs they have to cover, they said that every year there are more things added onto their plate that they are required to do with nothing being taken away to balance everything out. As an example, some of the newer initiatives implemented into classrooms have been programs that help in preparing students for the West Test. For instance, Tech Steps, Acuity, and Writing Road Map are all lessons and test preparation activities that every student must participate in and the teachers are expected to fulfill these expectations (Informant 1, Informant 2, Informant 11, and Informant 7). Consequently, non-instructional time at school tends to be used up on these extra obligations, and which in turn leads to all of their other responsibilities, such as grading papers, planning lesson plans, filling out administration forms and preparing materials for upcoming lessons, being completed outside of school hours, at home. This leads the next theme to be discussed which is all the extra work a teacher must do that is not compensated for and how this results in their labor being exploited.

\section{Labor Alienation}

Investigating aspects and indicators of labor alienation was the goal of this research. Specifically in the case for teachers, I was concerned with the amount of labor they expend in proportion to the salaries they are paid and how their labor is used. They are salary laborers, not hourly wage laborers so if any extra labor is used for their job 
outside of the contracted hours that they expected to fulfill during the school day, then there is extra labor the employer is receiving without having to provide compensation.

Within every contract a teacher signs when accepting a job position, the required number of hours they must be at school is specified, as well as listed and after those hours they are not required to be at school. Any extra time spent on school work or extra activities is not recognized or rewarded. Along with the contracted hours are the obligations and expectations of that job position that a teacher must perform. At the beginning of year a teacher signs their contract for the year and if they do not sign, then they are not employed. They either agree to the contract or lose their job.

What makes it hard for teachers is the fact that every year the county or school is allowed to add responsibilities to the contract, so the teacher has no choice but to agree to these new responsibilities. These additional responsibilities are not linked to a raise in salary or added benefits. Informant 7, was asked if teachers felt their labor was taken advantage of, they replied,

Yes and principals basically tell you that. You sign a contract and then in the contract it basically gives you your duties and any other assignments. So they can assign and add onto, which happens every year, it's like every aspect of society wants to funnel things through the general public education system. So things are added on every year and public school teachers are basically used and abused.

Similar sentiments on this topic were expressed by other interviewees.

There was a strong agreement among the teachers involved in this study on the need for extra time spent on work outside of school. Amongst the teachers interviewed, the amount of time spent working after school hours in the evening or during the weekends ranged from nothing less than 1 hour to 5 hours per day. Not one teacher said that they were able to get all their work completed during the school day hours. 


\begin{tabular}{|l|c|c|c|r|c|}
\hline \multicolumn{7}{|c|}{ Table 2.1 Average Annual Salary of Teachers } \\
\hline County & 2006 & \multicolumn{1}{|c|}{2007} & \multicolumn{1}{c|}{2008} & \multicolumn{1}{c|}{2009} & \multicolumn{1}{c|}{2010} \\
\hline Monongalia & $\$ 38,866$ & $\$ 39,957$ & $\$ 42,446$ & $\$ 44,634$ & $\$ 44,343$ \\
\hline $\begin{array}{l}\text { Percentage Change } \\
\text { from year before }\end{array}$ & & $2.81 \%$ & $6.23 \%$ & $5.15 \%$ & $-0.65 \%$ \\
\hline Preston & $\$ 39,044$ & $\$ 40,066$ & $\$ 41,795$ & $\$ 43,520$ & $\$ 43,496$ \\
\hline $\begin{array}{l}\text { Percentage Change } \\
\text { from year before }\end{array}$ & & $2.62 \%$ & $4.32 \%$ & $4.13 \%$ & $-0.06 \%$ \\
\hline
\end{tabular}

*Data acquired from The West Virginia Department of Education showing annual salary of teachers within Monongalia and Preston Counties.

One respondent commented,

I think the issue is that our state government expects teachers this day and age to do more with less and not be compensated, if anything we are going backwards because the cost of living is goes up, gasoline prices go up, health insurance goes up, our premiums go up but we are continuing to get paid the same amount of money. So it is actually instead of getting pay raises each year, you are getting paid less each year because you are spending more but getting paid the same (Informant 2, Date).

Several teachers also felt that if they were actually paid hourly, for all the work that they do in the evenings and on the weekends, they would be making more than they currently do (Informant 1, Informant 4, Informant 9). What is the most obvious when reviewing the comments associated with this issue is they are all aware and very conscious of these actions, but they cannot do anything about their current situation. This will be discussed further in the consequences section.

\section{Workplace Conditions}

What I was looking for with this theme was the relationships that the teachers had with the various levels of administrations/governments. This entailed addressing issues such as whether they felt support from their local school and county board office, and if they felt that the state supported them. Responses on these topics varied in attitude as 
well. Some felt support at one level, but not at another, while others were completely negative, while others were not necessarily positive but were more optimistic.

With any job or occupation, an employee is going to have employers or bosses that they are more in contact with than others. In the case of teachers in the public education system, it's their local school administration that they are in direct contact with and have more working relations with. Among the teachers that I talked to, there was was split when it came to working relations with their administrators. There were some that had no problems, while others did not like their administrations because they either thought they were doing things wrong or not supporting the teachers' decisions at the school (Informant 7, Informant 8). In general, there wasn't any teacher who absolutely was against the entire administration, though that doesn't mean that they didn't have some disagreements from time to time. For instance, Informant 7 mentioned that in one particular meeting an administrator openly told this teacher that if he or she didn't do as he or she was told do, then he or she would be regarded as being insubordinate.

As another example, one teacher felt overall, that the administration was good, but when it came down to certain issues they didn't feel supported, especially with regard to interactions with parents happy (Informant 6). He or she went on to offer an example. A student in their class handed in an assignment late because of an absence for an athletic event and they took points off the assignment. The students' parents complained to the administration, even though the student was informed by this teacher that they needed to turn in the assignment before the event to get full credit (Informant 6). The outcome of this situation was then explained, "I was visited by one of the four principals and told to change the grade, accept the work and change the grade. So there did I feel supported, no. 
I mean my authority in my own classroom was completely undermined. So do I fight things like that, I am not going to win" (Informant 6).

Impacts

I was concerned with decisions within the West Virginia education system that had impacts on teachers and their labor. There have been numerous decisions made at the state level concerning curriculum, new policies and educational initiatives in classrooms. All of these decisions have their own impacts, whether good or bad, they increase a teacher's spent labor in some way.

In most cases whenever a new decision is decided upon at the state level or even sometimes the federal level, teachers' inputs are rarely heard. Some teachers are lucky enough to actually be a part of the process of formulating policy and get to give their input, but as many of the teachers interviewed expressed, their input usually falls on deaf ears. One teacher I interviewed went to Washington D.C. with other teachers last year and met with legislators, to share their classroom experiences and offer input on educational issues. Although this teacher thought it was a great experience but as they went on to say, "I am not sure they took what we said into consideration" (Informant 11).

This was a theme throughout the interviews as well: the lack of teacher input into decisions being made about education seems to have had impacts on teachers themselves. More than a few stated that the state's push to keep trying new things in the classroom only adds to their work load and that the state never gives things enough time to see if something works before going on to something else (Informant 11, Informant 6, Informant 12). Other impacts that have affected teachers is the pressure from the state to 
accomplish all these things because federal funding is at stake, "So when federal dollars are at stake we do what we need to do" (Informant 6). This all has an impact on a teacher's performance level and labor because they need to do all these things which take away from the work that they feel they ought to be doing while at school.

\section{Consequences}

The concept of consequences is in some ways similar to that of impacts, but in the context of this research, the consequences that I am specifically looking for are the consequences of the actions of the state/government, at all levels. This includes, for example, consequences associated with No Child Left Behind, the ramifications of not scoring well in NCLB metrics in any year, and having a state-mandated curriculum I was particularly interested in the consequences that created working conditions that enabled the employer, the state, to get more labor out of their employees, the teachers, while in the same process not compensating the teachers for the extra work.

One major consequence has already been briefly discussed, namely the state taking over the Preston County board office operations. This followed low test scores over multiple years. One teacher I talked to has felt direct consequences of this, in not knowing about the security of her job (Informant 3). Another teacher said this they have

not felt much change other than more documentation that the teacher has to fill out during the course of a school day (Informant 9).

Another consequence that teachers have dealt with is the pressure they undergo that starts with the state wanting something, pressuring the county for it, which in turn gets passed off to the teachers to accomplish. The teachers' attitudes about this action 
appear to be one of frustration. If they are the instrument and means by which the state must accomplish what they want done in the education system, then why are they consulted in the process? One teacher articulated this frustration by describing what he/she felt was one of his/her biggest concerns with teaching in West Virginia.

One of the biggest discrepancies right now is that schools are being told, teachers are being told, rigor and relevance so they want it all the way up here [high level of content instruction] but schools are being scored on the number of kids who are graduating and who are dropping out and number of kids that are passing things like the West Test. So there is this problem, the teachers are saying, 'hey you told me to teach up here [high level of content instruction] and make it challenging and make it relevant and the kids aren't performing because they are stuck in that laziness and the administrators are saying we can't have all these students failing because then we can't get federal funding if we have kids dropping out and not graduating. So there is a discrepancy within the school between the administrators and the teachers and that is causing teachers to be unhappy because it is causing them to feel like they don't have the support that they need (Informant 11).

Frustration among teachers is common along with the constant exploitation of their labor because of poor compensation. This only makes things worse. In addition to this, it is hard for them to aggressively respond to these actions because as West Virginian public education teachers they are not allowed to have collective bargaining. Specifically, unions are not allowed to strike and to do so is grounds for job termination.

It is evident that some major themes of labor alienation have been revealed through these interviews. Teachers feel they are being mistreated. They feel they are undervalued as workers because of their lack of compensation and for the lack of, at times, the absence of respect from their administrators. Labor alienation is occurring because responses support the theme of unpaid and removal of autonomy over decisions 
concerning their labor. This issue will be the main theme to be discussed in the following chapter. 


\section{Chapter VII- Discussion}

Labor has long been the means by which humans survive. In most cases and for most of history, this labor takes the form of physical human labor, whether in agrarian or industrial societies. For the purposes of this study, the focus was on mental labor and how it fits in with theory that is primarily founded upon physical labor; whatever the type of labor, there is the potential and opportunity for alienation, as well as exploitation in some form or another.

When looking at physical labor, it is easier to measure the degrees of exploitation that occur because there are physical materials to base the labor in, like physical objects that are produced and wages earned for the labor. In the case of teaching, measuring the level at which exploitation occurs is slightly more difficult. As with other workers there is a time and activity delimited work day and wage, however, there is no material or physical or tangible object produced. Teachers produce knowledge in the classroom and so examining such a production can prove to be complex and because of this there is no for sure way to statistically measure if exploitation is occurring through the data collected. What is indicated is the presence of labor alienation.

\section{Labor Alienation}

Marx claimed that all human labor produces value; in essence it creates value in an object or good. It is through this direct human labor where both surplus value is created and where exploitation occurs. Exploitation is the act of extracting value through the enforcement of unpaid human labor in the production process. This process leads to the employer gaining the surplus or profit of the work. Since there is no material or 
tangible products being created by teachers, there can be no exact determination of what value is being extracted or levels of exploitation occurring. However, there are indicators that suggest that teachers' labor in the classroom is being alienating away from them based on the lack of input they have.

In the last several years, with the implementation of $21^{\text {st }}$ Century Learning into state schools, and because of such as things like Tech Steps at all levels of education, teachers' work has increased their workday by adding to the tasks they have to complete outside the rigid instruction time schedule. They have many obligations while constant interruption disturbs their flow of work. Assignments that are given to students must be graded and entered often after the end of the work day and on days off. Paperwork must be filled out daily, lesson plans need to be formulated, materials gathered for lessons, research done, etc. New objectives, which trickle down from the state and county take away from their planning time and even instructional time. There is no time left in the day to complete the rest of their work, so it must be done outside of the regular work hours, and therefore is uncompensated.

Since this is the case, it's obvious that given the definition of labor alienation laid out earlier, significant possibility for labor alienation exists among teachers. Teachers spend several hours outside of school working on various things to just stay caught up with everything that is required of them. They receive no extra pay for that work. Their pay is one of the lowest of professionals, and in West Virginia the pay of teachers is low compared to other states. Teachers are adding value even if it isn't exactly measurable or material at the moment of production. Indirectly, they are adding value to students who 
will one day use their own labor that will be guided by the knowledge instilled in them from their education. That knowledge value will manifest through them.

Where there is labor power, then there is value. Marx holds that all human labor instills value into the object that is being created eventually generating the surplus value that could be extracted from the labor power (Wolff, 1982). This study holds that teachers expend mental labor in a classroom and they produce knowledge. Since this knowledge is not of the material world, it is abstract and intangible. Value extraction from it must be viewed in circuits because there are no one ends to who profits or benefits. There are multiple circuits to this process. Teachers are paid by the state. They are state employees and thus the tax payers are ultimately paying their salaries because the state receives its income through taxes. So if it is viewed from that point, then the state is not the ultimate agent of the extraction of value.

I hold in this study that within these circuits of value movement, there are four main actors: the teachers, students, tax payers and the state. The students go to school to receive an education. This is taught to them by teachers. The state employs the teachers for their mental labor in the classroom and to produce knowledge, and the tax payers fund the state, indirectly funding the teachers. Overall, there are multiple actors who are on the receiving end of surplus value extraction in this process. The students receive their education, and the state pays teachers low pay and does not compensate for extra work, thus relieving tax payers of the obligation of higher taxes. Therefore, there is a double exploitation occurring within the teaching profession. The state, the teachers' direct employer, tax payers, the teachers' indirect employer, are profiting merely by the fact that they are not having to pay the teachers more money. There are several ways this 
process is enabled, but the largest contributor is the state, which will be discussed in the following section.

\section{Labor Alienation of Teachers by the State on Behalf of Taxpayers}

The market is a force that drives many decisions in the private sector and the government is not immune to such forces. Much of the government's involvement in education stems from legislature and policies like No Child Left Behind. This has trickled down into state systems, like West Virginia's. In the years since the adoption of NCLB, this policy has had many lasting effects on the public education system. These effects have set a path to opening the doors of for profit and market based education.

In West Virginia, NCLB facilitated the development of the West Test, a standardized test. Although there have been standardized tests in West Virginia in the past, they were not used to hold schools accountable for their students' test scores. The consequences of performing poorly on the West test include a possible takeover by the state. Every year schools have a standard they need to meet; this is known as Average Yearly Progress (AYP), and if a school fails to meet these standards several years in a row, there will be actions taken against them.

As an example, Preston County experienced low test scores and poor performance over several years. This led the state to take over the administrative structure of education in the county. Once a school has been labeled failing, the state has the option for closing the school and provides the option of vouchers and charter schools. Although this appears to be a good approach, in practice it has led to problems. This approach created an environment that has made poorer schools or counties more susceptible to the failings of 
low test scores and in most instances these are the more rural counties that have very little funding to invest into their schools. Preston County is one of these counties.

There have been many critics of this system. It has been argued that NCLB is a back door attempt by conservatives and neoliberals to promote their agenda of privatization and marketization (Apple, 2007). Furthermore, the standards have been set so high for schools that it appears "the aim of NCLB and other high stakes testing reforms therefore may be less about improving student learning and closing the achievement gap than it is about undermining public education to introduce a market based system" (Hursh, 2007, 504). Once a school is perceived to be failing, it can be shut down turning education into a product or commodity, something that can be bought by a consumer.

With a scenario like this, it takes very little effort to recognize the real agenda of NCLB. Transform a public good into a private one, ripe for hyper-exploitation of labor. Change to a more businesslike state, with a market based structure, and to facilitate exploitation of its workers, the teachers. Since teachers are the means by which the state offers the service of education, if private shareholders, whose main goal is to make a profit, enter the equation, then teachers' labor would be even more available for exploitation. They would have to sell their mental labor to their employers who would need to not pay for all the work that they would do so that a profit or surplus could be made. For instance, a for-profit school is run by private, profit-seeking companies and these schools operate as businesses. Profit, not education, is the main goal of an institution like this and thus a teacher's salary would be more subject to cuts or changes because, if profit is the school's concern, then cuts would be made to make money. 


\section{Consequences}

There are several consequences that the school systems in both Monongalia and Preston Counties have experienced already. One of the most evident consequences that can be seen is the frustration and stress levels found in teachers in both counties. The teachers I spoke to are unhappy with the amount of pay they receive, especially in relation to the amount of work they do outside of the classroom. They are disappointed in the actions of the state and the lack of support for teachers.

There is a consensus that the West Test and the initiatives that have been adopted because of it, like all the test preparation tests and technology programs are a waste of time. The consensus goes on to say that these programs only reinforce the idea that they are teaching for the West Test and not true educational standards. There is a feeling of disenfranchisement among teachers regarding the state of the public education system. This feeling is not about their profession itself, but mainly with how it is being governed and operated in the state. The lack of teacher input on decisions has caused distrust among teachers towards the educational administrators.

Overall, the involvement of the state of West Virginia in educational matters has not encouraged teachers. The hard stance the state takes on test scores and strict adherence to state initiatives, like Tech Steps and other programs geared to preparing for state tests, have overwhelmed teachers with large workloads and the stress of making sure everything is completed. Teachers are pressured by the state and administrators to make sure their students are ready for the state test, so that the scores will be high. Consequently, teachers are finding themselves teaching more for the West Test than 
teaching a curriculum based on what they feel their students need to know for the next grade level.

Consequences of the West Test are numerous. The state wants to see progress in its schools and to do that, knowledge has to be measured. This is done through the testing. Everything needs to be measured to see if it effective or not. There have been several studies and research done in states like New York and Texas that have shown the failings of the standardized tests and how administrations have manipulated figures and data to meet standards imposed on them. It's about numbers and money, as Apple (2007, 114) states,

"Thus, rather than schooling being aimed at creating critically democratic citizenship as its ultimate goal, the entire process can slowly become aimed instead at the generation of profit for shareholders or a site whose hidden purpose is to document the efficiency of newly empowered managerial forms within the now supposedly more business-like state".

Generally what is happening is data collection. Data is needed for the materialization of the market in the public education system. That is why standardized tests are used, "indeed, the movement toward marketization and choice requires the production of standardized data based on standardized processes and products so that comparisons can be made and so that consumers have relevant information to make choices on a market" (Apple, 2007, 111). Once data is collected and it reveals failing schools, they can then create options and choices for parents to choose from, thus paving the way for more infiltration of the market into the public education system.

What has been found is the evidential support that West Virginia Public education teachers in Monongalia and Preston Counties are experiencing processes of exploitation by the state. Whether it is being viewed through the already low pay they are receiving or 
the added assignments they are being given to complete without any compensation for the extra time that goes into accomplishing them, these teachers believe they are being asked to do more and more for less and less and they do not see an end in sight. 


\section{Chapter VIII- Conclusion}

The objective of this study was to examine the working conditions of a public education teacher in Monongalia and Preston County within the context of Marx's theory of surplus value extraction and theory of alienation. Areas were highlighted where alienation was occurring and its implications of the teachers themselves. Understanding the theory and the actions of the state were vital when examining the processes of alienation being carried out on teachers. Thus, this study was created to highlight and illustrate the act labor alienation and its impacts on public teachers in the current West Virginia education system.

A Marxist approach, along with qualitative methods, was utilized and applied to help explain the exploitation that was occurring through the use of labor power, mental labor and surplus value extraction. What was discovered was that teachers themselves feel lack of support from the employer, the state, and believe firmly that they are extremely under paid and uncompensated for the demanding workloads that they have. In both Monongalia and Preston Counties, teachers generally had negative attitudes towards the state and viewed them as being detached and uncaring regarding the needs of teachers. Examples of this were found in their responses concerning the state's disregard for teacher input, unresponsiveness to teacher demands and a general disconnected relationship with teachers.

It is through these processes that has deskilled and turned a public education teacher into an instrument for the state. Teachers feel they are there to only do the state's bidding. It is notable that a double exploitation occurs, where the state and taxpayers pay the least amount of money for the production of knowledge, while the West Virginia 
teacher is not getting fairly paid or compensated for all their extra work. All the while, the state is introducing new policies and legislation that will undermine and alienate more labor away from teachers by implementing more work with no additional pay. That also aids in undermining the entire public education system itself. This is accomplished, as shown, through the No Child Left Behind and all of its implications, including: standardized testing, high performance standards and the consequences for not meeting those standards that aid in ushering in a more private or business like education system.

\section{Limitations to this Study}

For the purposes of this thesis the theory of alienation was chosen as the more appropriate application to this study. Interpretations of interview responses did suggest that exploitation could be occurring and therefore value was being extracted in some form, which was a limitation to this study, however, there was no way measure any level of exploitation of any kind based on data collected and the research conducted. Also, I recognize that since the product of knowledge discussed in this study was clearly abstract and had no material basis, there is no way to measure the value that could be extracted from the labor power that went into the moments of production or any levels of exploitation. This was also the case for the concept of mental labor. I realize both of these aspects of the study are complex when trying to fit into a theory that was purely based in the physical and material world. However, I hold that the theory has been applied and used in the most appropriate way for these topics.

Although I believe qualitative methods were the most suitable course for data collection and analysis, it still presents its own limitations to the study. This approach was chosen purely on the fact that the teachers' perceptions and perspectives were 
necessary to the study and to understanding the level or levels of exploitation that were occurring. One particular limitation was the issue of time. Interviews were the primary form of data collection and thus were very time consuming. I interviewed a total of 13 teachers from Monongalia and Preston County. This does present a limitation to the study in the fact that there are many more teachers who work in these counties and their views and experiences are most likely different from the ones I spoke with.

While there are evident limitations to the study presented in this thesis, it does still represent a portion of the teaching community within Monongalia and Preston County which gives some illumination into their experiences and perceptions of their work environment. It cannot be said for sure that this is the case for every county in West Virginia. What can be said here is that within this study, public teachers in these two counties are experiencing labor alienation under the actions of this state. Although these teachers understand their circumstances and current working relations with the state, they still have very positive attitudes towards the profession of teaching itself. They believe it is a very respectable and important job within our society and they are determined to continue doing their job. They will, by no means, ever stop fighting for what they feel they deserve. 


\section{$\underline{\text { References }}$}

Aitkin, Stuart, "Shared Lives: interviewing couples, playing with their children", in Limb, Melanie and Dwyer, Claire (eds.), Qualitative Methodologies for Geographers: Issues and Debates, Oxford University Press: London, 2001.

American Federation of Teachers: A Union of Professionals. Survey and Analysis of Teacher Salary Trends 2007, retrieved from: http://www .aft.org/salaryl2007 /downloadl AFT2007SalarySurvey.pdf on September 3, 2009.

Apple, Michael W. "Ideological Success, Educational Failure?: On the Politics of No Child Left Behind." Journal of Teacher Education, 2007, Vol. 58, No.2, pp. 108116.

Bayles, Michael D. Professional Ethics. Belmont, California: Wadsworth, 1981.

Derber, Charles. Professionals as Workers: Mental Labor in Advanced Capitalism, Boston: G.K. Hall and Co., 1982.

Dunn, Kevin, "Interviewing", in Hay, lain (ed.), Qualitative Research Methods in Human Geography, 2nd ed. Melbourne, Oxford University Press, 2005.

Farber, Barry A., Crisis in Education: Stress and Burnout in the American Teacher, San Francisco and Oxford: Jossey-Bass Publishers, 1991.

Harvey, David, A Brief History of Neoliberalism, Oxford University Press: Oxford, 2005.

Harvey, David. The Limits to Capital, The University of Chicago Press: Chicago, 1982.

Hursh, David. "Assessing No Child Left Behind and the Rise of Neoliberal Education Policies." American Educational Research Association, 2007, Vol. 44, No.3, pp. 493-518.

Jackson, Peter, "Making sense of qualitative data", in Limb, Melanie and Dwyer, Claire (eds.), Qualitative Methodologiesfor Geographers: Issues and Debates, Oxford University Press: London, 2001.

Karp, Stan, (2003, November). The No Child Left Behind Hoax. Speech presented at Portland Area Rethinking Schools, Portland, OR.

Limb, Melanie and Dwyer, Claire, "Introduction: doing qualitative research in geography", in Limb, Melanie and Dwyer, Claire (eds.), Qualitative Methodologiesfor Geographers: Issues and Debates, Oxford University Press: London, 2001. 
Marx, Karl. Capital Vol. I, International Publisher Co.: New York, 1967.

No Child Left Behind (NCLB) Act of 2001, Pub. L. No. 107-110, § 115, Stat. 1425 (2002).

Ollman, Bertell. Alienation: Marx's Conception of Man in Capitalist Society, Cambridge U.P., 1971.

Ozga, Jennifer and Lawn, Martin. Teachers Professionalism and Class: A Study of Organized Teachers, London: Flamer Press, 1981.

Peace, Robin and Hoven, Bettina van, "Computers, Qualitative Data, and Geographic Research", in Hay, lain (ed.), Qualitative Research Methods in Human Geography, 2nd ed. Melbourne, Oxford University Press, 2005.

Shapiro, Stephen, How to Read Marx's Capital, Pluto Press: London, 2008.

Smith, Adam, The Wealth of Nations, Random House Publishing Group: New York, 2003.

Sweezy, Paul, The Theory of Capitalist Development. London: Modern Reader, 1942.

Walker, Richard, "Is There a Service Economy? The Changing Capitalist Division of Labor", in Barnes, Trevor; Peck, Jamie; Sheppard, Eric and Tiekell, Adam (eds.), Reading Economic Geography, Blackwell Publishing: Oxford, 2004.

Winchester, Hilary P. M., "Qualitative Research and its Place in Human Geography", in Hay, Iain (ed.), Qualitative Research Methods in Human Geography, 2nd ed. Melbourne,

Oxford University Press, 2005.

Rentschler, Thomas, "No Child Left Behind: Admirable Goals, Disastrous Outcomes." 2006, 12 Widener L. Rev. 637.

Ricardo, David, On the Principles of Political Economy and Taxation, 1817.

Whitaker, Albert C., History and Criticism of the Labor Theory of Value in English Political Economy, Batoche Books: Kitchener, 2001.

Wolff, Richard D., Bruce B. Roberts and Antonio Callari, "Marx's (not Ricardo's) 'Transformation Problem': A Radical Reconceptualization", History of Political Economy, 1982, Vol. 14, No. 4, pp. 564-82 


\section{Appendix A}

\section{$\underline{\text { Interview Questions }}$}

What grade do you teach? How long? Have you taught any other grades?

What county do you teach in? Any other counties?

How long have you been teaching?

What is your educational degree/specialization?

What was your starting salary and what is your current salary?

How much time are you required of you to be at school during one school day? How much time are you actually there?

What do you usually do during a normal school day, what is required of you to do?

How much time would you say you spend outside of school, whether at home in the evenings or on the weekends, working on school work?

Are teachers taken advantage of through the amount of work they are expected to perform? And in what ways?

On average, what is class size usually at? Do find that amount manageable?

Do you know what the legal limit for students allowed in a classroom?

When it comes to teaching lessons in the classroom and the curriculum that you are presenting to your students, do you feel you have control over that or do you feel a lot of its mandated and things that you feel like you have to cover?

So you do feel that you have some creativity when it comes to your lessons?

Have you ever felt pressured by either the school administration or the county to teach certain things or in a certain way?

Is most of the curriculum created by the county or the state?

What are some of the newer initiatives that have been created recently in the state?

With all these new initiatives being brought in, do you feel as a teacher you are being held to unrealistic demands by trying to get everything done? 
Now do you find that you have support with, support with anything during your daily routine from either the school administration or the county, I mean do you feel like you have support in your decisions?

What about from the like parents or the community, do you feel support from them as a teacher?

Now how do you feel about how the profession of teaching among other professions are on the lower end of the spectrum and paid almost near to nothing compared to other ones? I mean, do you feel teachers are compensated fairly for the work that they do?

Do you feel that you are a professional because of the degree that you have attained?

Do you feel that you relate to other profession statuses or do you feel like you almost more relate to a working class?

How do you think non-teachers perceive the profession of teaching?

Do you think that is because of what you are paid or because of what you feel your job is valued?

What about in your own school, do you feel valued there?

Do you feel you have good working conditions?

Do you feel that you are compensated or paid fairly for the work that you do?

What about your working relations with either the school itself, like the administration or the county, do you feel that they are good relations?

Are you member of a teacher union? If so, why and if not, why?

Are teacher unions appealing to teachers?

Do you think teachers are motivated to always do their best or just do enough work to get by usually?

What reasons led you to become a teacher?

In what ways would you change the structure or framework of the public education system or is it fine the way it is?

What are some of the biggest concerns that teachers have for the teaching profession today? In the future? 


\section{Appendix B}

\section{WestVirginiaUniversity}

Eberly College of Arts and Sciences

\section{Dear Participant,}

This letter is a request for you to take part in a Master's Thesis research project that is interested in identifying how teachers' labor is valued by the community and the state. The following interview contains questions that seek to understand how the average West Virginian teacher's hard work is valued. This project is being conducted by Lindsey Felton, a MA candidate in the Geography program, under the supervision of Dr. Brent McCusker, an associate professor in Geology and Geography department, for a Master's Degree in Research. Your participation in this project is greatly appreciated and this interview will take no more than an hour to complete.

Your involvement in this project will be kept as confidential as legally possible. All data will be reported in the aggregate. You must be 18 years of age or older to participate. I will not ask any information that should lead back to your identity as a participant and I ask that you do not respond with any information that you may feel may be linked back to your identity. Your participation is completely voluntary. If at any time you feel uncomfortable with a question, you are under no obligation to respond. You may request to skip any question that you do not wish to answer and you may discontinue at any time. You should be aware that anything said during the interview process will be potential data for this project. Your class standing will not be affected if you decide either not to participate or to withdraw. West Virginia University's Institutional Review Board acknowledgement of this project is on file. All interview responses will be kept confidential and will be for the researcher's use only.

I hope that you will participate in this research project, as it could be beneficial in understanding the implications that local and state policy have on the teaching profession. Thank you very much for your time. Should you have any questions about this letter or the research project, please feel free to contact Lindsey Felton at (304) 290-4234 or by email at lfelton1@ mix.wvu.edu.

Thank you for your time and help with this project.

Sincerely,

Lindsey Felton 


\section{Appendix C}

\section{Interview Consent Form}

I, the participant of this interview consent to this interview process. I am aware and acknowledge the purpose and goals of this project and understand the information presented to me about this project. I have read the cover letter for this interview and I allow the researcher to use my responses collected during the interview process for the development of this research project.

Print Name

Signature

Date 